Danica Bakotić
Marin Buble $^{2}$
UDK 65.015.25:331.101.62

Preliminary paper

Prethodno priopćenje

\title{
RELATIONSHIP BETWEEN KNOWLEDGE WORKERS' PARTICIPATION AND ORGANIZATIONAL PERFORMANCE
}

\begin{abstract}
The aim of this paper is to prove the connection between the participation of knowledge workers in an organization and its performance, as well as to define how the change of the participation of knowledge workers influences organizational performance. The empirical research was conducted on a sample of 40 companies. Using a specially designed questionnaire, the research data, which includes data about the participation of knowledge workers in each company and indicators of companies' financial performances, was collected. The empirical results discovered a statistically significant positive correlation between knowledge workers' participation and organizational performance and also showed how each financial indicator of a company's performance will change if the knowledge workers' participation changes. Furthermore, the results show that the growth of knowledge workers' participation in companies is not adequately followed by increased awards and other expenditures related to these workers, which could be a significant factor of the low productivity of these workers, which has also been proved by this research.
\end{abstract}

Key words: knowledge workers, organizational performance, productivity

\section{INTRODUCTION}

Since P. Drucker introduced the term of knowledge workers for the first time, this concept has come into the focus of theory and scientists as well as of practice and managers. Knowledge workers could be defined as workers whose work is based on the knowledge gained through their formal education or work experience; in their work they are looking for challenges and respond to them by creating new solutions or upgrades. In this way, they contribute to the development of their profession and the company in which they are employed. Some authors define these workers by their education. Bentley (1990) defines knowledge workers as those with high education, while Janz et al. (1997) identify knowledge workers as the ones who implement their theoretical and analytical knowledge gained during the educational process through which they have passed.

The contribution of knowledge workers to the organizational performance was the subject of many researches. Harris and Vining (1987) in their research emphasize the role of knowledge workers in added value creation. Harrigan and Dalmia (1991) highlight their importance as enterprises' intangible assets. Many authors have dealt with the motivation, productivity and rewards of knowledge workers (Despres and Haltrop, 1996; Baron and

\footnotetext{
${ }^{1}$ Doc. dr. sc. Danica Bakotić, University in Split, Faculty of Economics, Matice hrvatske 31, 21000 Split, e-mail: danicab@efst.hr

2 Prof. dr. sc. Marin Buble, University in Split, Faculty of Economics, Matice hrvatske 31, 21000 Split, e-mail: mbuble@efst.hr
} 
Hannan, 2002; Roell, 2004; Davenport, 2003; May et al., 2002; Karr-Wisniewski and Lu, 2010) as crucial determinants of organizational performance.

This paper tries to clarify the relationship between knowledge workers' participation and organizational performance by answering two questions:

(1) What is the relationship between knowledge workers' participation and organizational performance?

(2) How will organizational performance change if the knowledge workers' participation changes?

In order to answer these questions, an empirical research was conducted. To investigate the contribution of knowledge workers to organizational performance, it was important to distinguish knowledge workers from other employees. For this purpose, Bentley's (1990) definition of knowledge workers was followed. As it is already stated, he defines knowledge workers as those who have high education. Although this definition is not precise because knowledge workers are not all employees with a university degree, it represents the clearest way to determine the number of knowledge workers in some company. Organizational performance, as the other research variable, was explored by the financial indicators of organizational performance. The financial indicators, as a determinant of organizational performance, are commonly used by many authors in different researches (Snow and Hrebiniak, 1980; Barry and Milkovic, 1990; Huselid, 1995; Rechner and Dalton, 1991; Flamholtz and Hua, 2002; Schulte et al., 2009; Xing, 2009; Choi et al., 2010; O'Boyle et al. 2010; Munoz-Bullon and Sanchez-Bueno, 2010).

The research results of this paper confirm the importance of knowledge workers for companies' performance and clarify their contribution in achieving a specific level of organizational performance.

This paper starts with a theoretical background of knowledge workers and organizational performance (Section 2) which is needed for the proper understanding of the research topics. The research methodology is presented in Section 3, which is followed by the research results in Section 4. Concluding remarks are in Section 5, and the research limitations and guidelines for future research are presented in Section 6.

\section{LITERATURE OVERVIEW}

\subsection{Knowledge workers and their role in contemporary companies}

Knowledge workers are the generators of a company's growth and development. Their importance in modern companies is tremendous and it is defined by their knowledge possession, by their competences and abilities to solve the most complex problems and to develop new advanced and better solutions which will provide competitive advantage to the companies in which they are employed. Knowledge workers arise as a result of demands in the creation of new workplaces which are an essential form of modern companies. These types of workplaces require a considerable formal education and an ability to acquire and apply knowledge. Thus, the tasks which the knowledge workers have to complete require a different working approach and the need for permanent learning.

The definitions of knowledge workers refer to the context in which these workers perform their everyday jobs. Drucker (1959) defines knowledge workers as those who create new information which could be used in the decision-making process and for problem solving. Vogt (1995) defines knowledge workers as individuals who have the capacity and motivation to create new views, who have developed communication skills, who are able to transfer knowledge and create possibilities for using new ideas. Knowledge workers are workers who have individual and personal knowledge, and organizations are increasingly seeking ways of transforming this into shared social knowledge deployed for organizational goals (Frost, 
2002). These workers consider that the sharing and transfer of their knowledge and expertise is their personal and professional responsibility (Redpath et al., 2009, pp. 86). Frost et al. (2010) define knowledge workers as a critical resource to the firm because their abilities must contain firm-specific knowledge to gain a sustainable competitive advantage (Frost et al., 2010, pp 127). Knowledge workers are also defined through different professions such as scientists, engineers, professors, psychologists, lawyers, bankers, accountants, etc.

The analysis of the importance of knowledge workers, their place and their role in modern companies should start from a broader range which contains general characteristics and elements of present-day society. Namely, the dominant characteristic of today's society is a strong competition. Access to information is free; the knowledge is available to everybody, so there is no excuse for poor performances. The competition becomes considerably strong on the individual level as well as on the organizational and general social level. In these circumstances, the importance of knowledge workers becomes clearly evident. These workers have to convert their knowledge into outstanding performances.

The majority of knowledge workers spend all their working life like other employees. They have their workplace; they get a salary, and could be fired. However, contrary to other employees, knowledge workers possess the most important resource, knowledge. Industrial workers leaving a company leave behind the machines and equipment, but when knowledge workers leave a company, they take away the most valuable company's resource and that is their knowledge. Therefore, the key investment of modern companies is not the investment in facilities, buildings and equipment but in knowledge and knowledge workers. Without knowledge workers, no matter how sophisticated and advanced the company's technology is, it will not be effective and efficient.

Knowledge workers and the organization in which they work are interdependent. Specifically, the organization provides knowledge workers the resources (Alverson, 2000). Only knowledge without organizational support and resources is worthless. On the other hand, companies depend on knowledge workers and their ability to synthesize theoretical and empirical knowledge in order to apply it to design appropriate solutions. In this sense, companies must meet the aspirations and expectations of knowledge workers which will cause their dedicated efforts in achieving companies' goals. The companies in which they are employed should provide them with the adequate resources necessary for their knowledge application and building satisfactory solutions. Furthermore, the companies should also offer them the resources for their sustained development as a precondition for exceptional performances, both individual and organizational ones.

According to these thoughts and the growing interest in understanding the importance and meaning of knowledge workers in today's companies as well as their contribution to the whole society, this term comes into the focus of scientists and managers. In literature, there are many papers which analyze knowledge workers from different aspects such as characteristics and expectations of knowledge workers; learning organizations as a new organizational form; knowledge management; etc. (Horwitz et al., 2003). Arthur et al. (2008) in their article address the special circumstances that confront the contemporary knowledge worker in the unfolding knowledge economy. Wang et al. (2009) in their paper analyze the knowledge workers' turnover rate and discover the importance of their intrinsic characters as determinant of their turnover. Similarly, Wu (2009) in his paper suggests that because of knowledge workers' different characteristics from common workers, the effective management for them should be based on their unique characteristics.

\subsection{Organizational performance measurement}

The identification of organizational performance fundamentally represents the determination of organizational success, which in present circumstances becomes extremely 
important because of many reasons such as: growing competition, business reengineering, national and international quality rewards, organizational changes, regulation and deregulation, development of IT, etc. (Neely, 1999). Performance measurement is a crucial requirement of the performance management as a tool for achieving better individual, team and organizational results (Armstrong, 2006, pp. 184). The organizational performance essentially could be determined by either financial indicators or contemporary performance measurement systems.

The financial indicators of organizational performance represent the dominant category in a group of traditional measurements of organizational performance. These indicators are oriented towards the determination of a company's market efficiency and they include indicators which are assigned by market demand, competition, etc. The calculation of these indicators is based on financial statement analysis. The financial indicators include: activity analysis (which usually involves the calculation of the total asset turnover ratio, current asset turnover ratio, days sales outstanding); calculation of the economy ratio or revenues over expenses ratio; liquidity analysis (which usually involves the current ratio and quick or acid test ratio); debt analysis (which includes the calculation of the debt ratio, times-interestearned (TIE) ratio, EBITA coverage ratio); profitability analysis (which includes the calculation of the profit margin on sales, basic earning power ratio, return on total assets, return on equity); and market value ratios such as the price/earnings ratio, price/cash flow ratio, and market/book ratio (Žager and Žager, 1999; Brigham and Daves, 2001). The selection of these indicators depends on the research topic (Škerlavaj et al., 2007; Gursoy and Swanger, 2007; Jing and Li, 2008; Dotson and Allenby, 2010). In that context, besides the mentioned indicators, one could calculate some other financial indicators which could be important in the explanation of the interdependence between research variables. For example, the labor cost per worker could be an indicator of companies' investment in their workers (salaries, training, development, etc.), thus it could be a determinant of organizational performance. However, today, many authors question the exclusive reliance on financial indicators as the only criterion of organizational performance determination, emphasizing that these indicators are mainly used for reporting, rather than to analyze the successful implementation of the strategy and determining the future direction of company development (Ghalayini and Noble, 1996; Neely, 1999; Wade and Recardo, 2001; Niven, 2007).

The organizational performance could also be determined by modern performance measurement approaches or models which are developed in order to include and balance the multidimensional aspects of a company's performance, no matter whether they are quantitative or qualitative ones (Keegan et al., 1989; Cross and Lynch, 1989; Fitzgerald et al., 1991; Kaplan and Norton, 1992; Brown, 1996). However, there are no clear instructions which modern performance measurement approach or model should be used in order to compare different companies, which are mainly of different size and belong to different industries. From the perspective of scientific research, significant shortcomings of new modern performance measurement models regard the lack of a clear definition of organizational performance measurement models, which very often do not provide the possibility of comparing companies. As a result, many scientists give priority to financial indicators that give opportunity to compare different companies. Financial indicators have the same way of calculation regardless of the company size or industry in which they belong, so they facilitate the research realization, analysis of the results and generation of the conclusions. 


\section{RESEARCH METHODOLOGY}

This research into the relationship between knowledge workers' participation and organizational performance is a part of a large investigation of job satisfaction and organizational performance which is being conducted on a sample of 40 large and mediumsized Croatian companies which employ 5,806 workers; out of that, 736 are knowledge workers. At first sight, the research sample of 40 companies seems a small one, but regarding the research topic which connects two very sensitive dimensions that are job satisfaction and organizational performance, it could be stated that the sample size is adequate. Many other relevant researches of job satisfaction or some other aspect of organizational behavioral is conducted on a much smaller sample (Herzberg et al., 1959; Sy et al., 2006; O’Connor, 2007; Sharma and Jyoti, 2010; Santhapparaj and Alam, 2005; Bender et al., 2005; Bender and Heywood, 2006). Additionally, it is important to state that this research sample adequately represents the Croatian economic structure regarding the companies' size, their industry belongings, and their organizational performances.

In the context of the representativeness of the research sample, regarding the participation of knowledge workers, it could be stated that the research sample is a representative one. A greater number of companies, i.e. $33.3 \%$ of them, has from 10 to $20 \%$ of knowledge workers. Then follow the companies which employ up to $10 \%$ of knowledge workers $(30.8 \%$ of companies in the sample). Concerning that the participation of highly educated employees in the total number of employees in Croatian companies in 2009 is about $17.7 \%^{3}$, it could be concluded that the majority of companies from the sample confirm this average which suggests its representativeness. Regarding organizational performance, it could be also stated that the research sample is a representative one because it includes the companies of different levels of organizational performance. Namely, regarding the composite BEX index as an indicator of the total business performance, $51.3 \%$ of companies from the sample are "good companies" (BEX $>1)$, 38.5\% of companies need some improvements $(0<\mathrm{BEX}<1)$, while $10.2 \%$ of them has a threatened existence $(\mathrm{BEX}<0)$.

The empirical research was conducted in 2008. A research questionnaire was used with two groups of questions. The first group contains two questions; a question about the total number of employees, and a question about the number of knowledge workers - which are defined as workers with a university degree (Bentley, 1990). The second group of questions was about the financial organizational performance of each company (for example, the total assets, total revenue, interest costs, equity, current assets, long-term debt, etc.) The questionnaire was fulfilled by the chief accountant of each company.

On the base of collected data, the participation of knowledge workers in each company is calculated, as well as 15 financial indicators of organizational performance. These indicators are: total asset turnover ${ }^{4}$, current asset turnover ${ }^{5}$, revenues over expenses ratio ${ }^{6}$, return on assets $^{7}$, return on equity ${ }^{8}$, ROCE ${ }^{9}$, revenue per employee, earnings before taxes per employee, labor costs per employee, revenue per knowledge worker, earnings before taxes per knowledge worker, labor costs per knowledge worker, approximation of value added ${ }^{10}$,

\footnotetext{
${ }^{3}$ According to data from the Statistical Yearbook of the Croatian Republic in 2010.

${ }^{4}$ Total asset turnover $=$ Total revenues/Total assets

${ }^{5}$ Current asset turnover $=$ Total revenues/Current asset

${ }^{6}$ Revenues over expenses ratio $=$ Total revenues/Total expenses

${ }^{7}$ Return on assets $=($ Earnings before taxes + Interest expenses $) /$ Total assets

${ }^{8}$ Return on equity $=$ Net income/Shareholder Equity

${ }^{9}$ ROCE $=$ (Net income/Total assets $)-$ Short term liabilities

${ }^{10}$ Approximation of value added = Labor costs + Earnings before taxes
} 
approximation of value added per knowledge worker and the $\mathrm{BEX}^{11}$ index. These indicators were selected because they provide the relevant information about the overall organizational performance regarding the nature of research variables. The collected data was processed by defined statistical methods using the program SPSS.

\section{RESEARCH RESULTS}

The empirical results of this paper provide the analysis of the correlation between knowledge workers' participation and organizational performance and show how the knowledge workers' participation changes the influence on specific financial indicators of organizational performance. The statistical analysis shows the existence of statistically significant correlations between knowledge workers' participation and some financial indicators of organizational performance which are presented in Table 1, while other correlations (statistically not significant) are presented in Table 2.

\footnotetext{
${ }^{11} \mathrm{BEX}=0,388 \mathrm{ex} 1+0,579 \mathrm{ex} 2+0,153 \mathrm{ex} 3+0,316 \mathrm{ex} 4$; where: $\mathrm{ex} 1=($ Earnings before taxes + Interest expenses $) /$ Total assets; ex2 = Earnings before taxes/Equity*Cost of capital (interest rate); ex3 = (Current assets - Short term liabilities)/Total assets; ex $4=5 *($ Earnings before taxes + Amortization $) /$ Total liabilities
} 
Table 1. Statistically significant correlations between knowledge workers' participation and financial indicators of organizational performance

\begin{tabular}{|c|c|c|c|c|c|c|c|c|c|c|}
\hline & & (1) & (2) & (3) & (4) & (5) & (6) & (7) & (8) & (9) \\
\hline (1) & Pearson & 1 & & & & & & & & \\
\hline Knowled & Correlation & & & & & & & & & \\
\hline $\begin{array}{c}\text { ge } \\
\text { workers' }\end{array}$ & $\begin{array}{l}\text { Sig. (2- } \\
\text { tailed) }\end{array}$ & 36 & & & & & & & & \\
\hline $\begin{array}{l}\text { participat } \\
\text { ion }\end{array}$ & $\mathrm{N}$ & & & & & & & & & \\
\hline (2) & Pearson & $.665 *$ & 1 & & & & & & & \\
\hline Revenue & Correlation & $*$ & & & & & & & & \\
\hline $\begin{array}{c}\text { per } \\
\text { employee }\end{array}$ & $\begin{array}{l}\text { Sig. (2- } \\
\text { tailed) } \\
\mathrm{N}\end{array}$ & $\begin{array}{r}.000 \\
36\end{array}$ & 36 & & & & & & & \\
\hline (3) & Pearson & & & 1 & & & & & & \\
\hline Revenue & Correlation & $363 *$ & $.824 *$ & & & & & & & \\
\hline per & Sig. (2- & & * & 36 & & & & & & \\
\hline $\begin{array}{l}\text { knowledg } \\
\text { e worker }\end{array}$ & $\begin{array}{l}\text { tailed) } \\
\mathrm{N}\end{array}$ & . 029 & $\begin{array}{r}.000 \\
36\end{array}$ & & & & & & & \\
\hline & & 36 & & & & & & & & \\
\hline (4) Labor & Pearson & $.829 *$ & & .157 & 1 & & & & & \\
\hline costs per & Correlation & * & $.373 *$ & . 360 & & & & & & \\
\hline employee & Sig. (2- & & & 36 & 36 & & & & & \\
\hline & tailed) & .000 & .025 & & & & & & & \\
\hline & $\mathrm{N}$ & 36 & 36 & & & & & & & \\
\hline (5) Labor & Pearson & - & -.271 & - & -.242 & & & & & \\
\hline costs per & Correlation & $.569 *$ & .110 & .011 & .155 & 1 & & & & \\
\hline knowledg & Sig. (2- & * & 36 & .951 & 36 & & & & & \\
\hline e worker & tailed) & .000 & & 36 & & & & & & \\
\hline & $\mathrm{N}$ & 36 & & & & 36 & & & & \\
\hline (6) & Pearson & & .050 & - & & - & 1 & & & \\
\hline Earnings & Correlation & $.501 *$ & .770 & .067 & $.483^{*}$ & .265 & & & & \\
\hline before & Sig. (2- & * & 36 & & * & & 36 & & & \\
\hline taxes per & tailed) & .002 & & .700 & .003 & .119 & & & & \\
\hline employee & $\mathrm{N}$ & 36 & & 36 & 36 & & & & & \\
\hline & & & & & & 36 & & & & \\
\hline (7) & Pearson & & -.051 & - & & - & & 1 & & \\
\hline Revenues & Correlation & $.454 *$ & .767 & 172 & $.458^{*}$ & .319 & $.885 *$ & & & \\
\hline over & Sig. (2- & * & 36 & .315 & * & & * & 36 & & \\
\hline expenses & tailed) & .005 & & 36 & .005 & .058 & & & & \\
\hline ratio & $\mathrm{N}$ & 36 & & & 36 & & .000 & & & \\
\hline (8) & Pearson & & & & & 36 & $\begin{array}{r}36 \\
.131\end{array}$ & .261 & 1 & \\
\hline Return of & Correlation & $.605 *$ & $.663 *$ & $.521 *$ & $.350 *$ & $.380 *$ & .446 & .124 & & \\
\hline equity & Sig. (2- & * & * & * & .036 & & 36 & 36 & 36 & \\
\hline & tailed) & .000 & .000 & .001 & 36 & .022 & & & & \\
\hline & $\mathrm{N}$ & 36 & 36 & 36 & & & & & & \\
\hline & & & & & & 36 & & & & \\
\hline (9) BEX & Pearson & & & & .275 & - & & & & 1 \\
\hline & Correlation & $.468^{*}$ & $.579 *$ & $.524 *$ & 109 & . 181 & $.339 *$ & $.413 *$ & $.888 *$ & \\
\hline & Sig. (2- & * & * & * & 35 & & .046 & .014 & * & 35 \\
\hline & tailed) & .005 & .000 & & & .297 & 35 & 35 & .000 & \\
\hline & $\mathrm{N}$ & 35 & 35 & .001 & & & & & 35 & \\
\hline & & & & 35 & & 35 & & & & \\
\hline
\end{tabular}


Table 2. Other correlations between knowledge workers' participation and financial indicators of organizational performance

\begin{tabular}{|c|c|c|c|c|c|c|c|c|c|}
\hline & & (1) & (2) & (3) & (4) & (5) & (6) & (7) & (8) \\
\hline $\begin{array}{l}\text { (1) Knowledge } \\
\text { workers' } \\
\text { participation }\end{array}$ & $\begin{array}{l}\text { Pearson } \\
\text { Correlation } \\
\text { Sig. (2- } \\
\text { tailed) } \\
\mathrm{N}\end{array}$ & 36 & & & & & & & \\
\hline $\begin{array}{l}\text { (2) Total assets } \\
\text { turnover }\end{array}$ & $\begin{array}{l}\text { Pearson } \\
\text { Correlation } \\
\text { Sig. (2- } \\
\text { tailed) } \\
\mathrm{N}\end{array}$ & $\begin{array}{r}-.157 \\
.360 \\
36\end{array}$ & 36 & & & & & & \\
\hline $\begin{array}{l}\text { (3) Current asset } \\
\text { turnover }\end{array}$ & $\begin{array}{l}\text { Pearson } \\
\text { Correlation } \\
\text { Sig. (2- } \\
\text { tailed) } \\
\mathrm{N}\end{array}$ & $\begin{array}{r}- \\
.168 \\
.335\end{array}$ & $\begin{array}{r}.994 * * \\
.000 \\
35\end{array}$ & 36 & & & & & \\
\hline $\begin{array}{l}\text { (4) Return on } \\
\text { assets }\end{array}$ & $\begin{array}{l}\text { Pearson } \\
\text { Correlation } \\
\text { Sig. (2- } \\
\text { tailed) } \\
\mathrm{N}\end{array}$ & $\begin{array}{r}35 \\
-.095 \\
.586 \\
35\end{array}$ & $\begin{array}{r}.984 * * \\
.000 \\
35\end{array}$ & $\begin{array}{r}.981 * * \\
.000 \\
35\end{array}$ & 36 & & & & \\
\hline (5) ROCE & $\begin{array}{l}\text { Pearson } \\
\text { Correlation } \\
\text { Sig. (2- } \\
\text { tailed) } \\
\mathrm{N}\end{array}$ & $\begin{array}{r}. .145 \\
.405 \\
35\end{array}$ & $\begin{array}{r}.993 * * \\
.000 \\
35\end{array}$ & $\begin{array}{r}.997 * * \\
.000 \\
35\end{array}$ & $\begin{array}{r}.989 * \\
.000 \\
35\end{array}$ & 36 & & & \\
\hline (6) Earnings & Pearson & .311 & .244 & $.509 *$ & $.611^{* *}$ & $.534 * *$ & 1 & & \\
\hline $\begin{array}{l}\text { before taxes per } \\
\text { knowledge } \\
\text { worker }\end{array}$ & $\begin{array}{l}\text { Correlation } \\
\text { Sig. (2- } \\
\text { tailed) } \\
\mathrm{N}\end{array}$ & $\begin{array}{r}.065 \\
36\end{array}$ & $\begin{array}{r}.151 \\
36\end{array}$ & $\begin{array}{r}.002 \\
35\end{array}$ & $\begin{array}{r}.000 \\
35\end{array}$ & $\begin{array}{r}.001 \\
35\end{array}$ & 36 & & \\
\hline $\begin{array}{c}\text { (7) } \\
\text { Approximation } \\
\text { of value added }\end{array}$ & $\begin{array}{l}\text { Pearson } \\
\text { Correlation } \\
\text { Sig. (2- } \\
\text { tailed) } \\
\mathrm{N}\end{array}$ & $\begin{array}{r}.171 \\
.318 \\
36\end{array}$ & $\begin{array}{r}-.049 \\
.775 \\
36\end{array}$ & $\begin{array}{r}-.048 \\
.785 \\
35\end{array}$ & $\begin{array}{r}.023 \\
.895 \\
36\end{array}$ & $\begin{array}{r}-.060 \\
.733 \\
35\end{array}$ & $\begin{array}{r}.118 \\
.492 \\
36\end{array}$ & 36 & \\
\hline 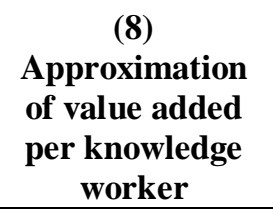 & $\begin{array}{l}\text { Pearson } \\
\text { Correlation } \\
\text { Sig. (2- } \\
\text { tailed) } \\
\mathrm{N}\end{array}$ & $\begin{array}{r}-.120 \\
.484 \\
36\end{array}$ & $\begin{array}{r}.486^{* *} \\
.003 \\
36\end{array}$ & $\begin{array}{r}.666^{* *} \\
.000 \\
35\end{array}$ & $\begin{array}{r}-.091 \\
.596 \\
36\end{array}$ & $\begin{array}{r}.646^{* *} \\
.000 \\
35\end{array}$ & $\begin{array}{r}.597 * * \\
.000 \\
36\end{array}$ & $\begin{array}{r}-.001 \\
.996 \\
36\end{array}$ & 36 \\
\hline
\end{tabular}

Source: Authors' calculations

A statistically significant positive correlation between knowledge workers' participation and financial indicators of organizational performance is apparent in the case of seven financial indicators among 15 of them. A strong positive correlation ( $r>0.80)$ exists between the knowledge workers' participation and labor costs per employee. A correlation of medium intensity $(0.50<\mathrm{r} \leq 0.80)$ is found between the knowledge workers' participation and revenue per employee; earnings before taxes per employee and return on equity. A positive correlation of weak intensity $(0<\mathrm{r} \leq 0.50)$ is manifested in the case of the knowledge workers' participation and revenue per knowledge worker; revenues over expenses ratio and the BEX index. A statistically significant negative correlation is defined between the knowledge workers’ participation and labor costs per knowledge worker. 
The above presented correlations could indicate the existence of the relationship between the knowledge workers' participation and some financial indicators of organizational performance. It should be pointed out, however, that the determined correlations are not strong ones, which is expected because of many different factors, internal and external, which influence and determine the organizational performance. For that reason, in order to generate some conclusions, it is necessary to explore and analyze the defined correlations.

It is interesting to note the existence of a statistically significant negative correlation of medium intensity between the knowledge workers' participation and labor costs per knowledge worker. This correlation suggests that when the number of knowledge workers increase, the costs related to these workers fall. Thus, the increase of the number of knowledge workers is not followed by increased rewards and other expenses which are related to these workers such as salaries, training costs, specializations, benefits, etc. A statistically significant positive correlation of strong intensity is defined between knowledge workers' participation and labor costs per employee. The existence of this kind of correlation is very logical because the growing number of knowledge workers should increase labor costs related to all employees. Regarding these two correlations, it should be noticed that if the number of knowledge workers grows, the total labor costs also increases. However, if the number of knowledge workers grows, the labor costs related to them decrease. Thus, this suggests that the growing number of knowledge workers is not followed by the increasing expenditure related to these workers which should be the companies' practice. This affects organizational performance in a way that the contribution of knowledge workers could be diminishing because of the low companies' investment which regards their salaries, bonuses, training and other factors which could motivate them on better performances.

Furthermore, a statistically significant positive correlation of medium and low intensity should be closely observed. A statistically significant positive correlation of medium intensity is detected between the knowledge workers' participation and profitability ratios (earnings before taxes per employee and return on equity), as well as between the knowledge workers' participation and revenue per employee, which indicate a significant importance of knowledge workers for companies' performance because these financial indicators show the companies' efficiency.

A statistically significant correlation of low intensity implies a weak connection between the knowledge workers' participation and revenue per knowledge worker; revenues over expenses ratio and the $\mathrm{BEX}$ index. All these financial indicators are related to revenue (revenue is the crucial element in their calculations), and knowing that revenue is a measure of productivity, these correlations open some important questions about the knowledge workers' productivity. It could be therefore stated that these workers are not more productive than other employees. This is not a surprise. More than 10 years ago, P. Drucker pointed out that the productivity of knowledge workers is on a low level and that the improvement of their productivity is one of the most important challenges of modern companies (Drucker, 1999). In this context, he does not refer to the productivity which is individually defined but to the productivity which is organizationally determined. This means that the low knowledge workers' productivity is not mainly the result of their individual effort and engagement but rather the result of poor organizational conditions and an organization's disability to use the potential of knowledge workers. The change of this situation could not be based only on knowledge workers' motivation but on the development of integral organizational conditions as requirements for creative and efficient knowledge implementation.

Regardless of these open questions about knowledge workers' productivity, the above presented results show the existence of a statistically significant correlation between the knowledge workers' participation and certain indicators of organizational performance. 
Among these financial indicators, the BEX index should be mentioned as a reliable indicator of the companies' overall business excellence.

In order to conduct additional analysis, in the following section, the impact of knowledge workers' participation change on financial indicators of organizational performance will be calculated, which means that further analysis will give the answer to the question of how much each indicator of organizational performance will change (rise or decline) if the knowledge workers' participation changes by $1 \%$.

The linear regression is used for this analysis. The model of this regression is:

where:

$$
\mathrm{Y}_{\mathrm{i}}=a+b \mathrm{X}
$$

$Y_{i}$ - each financial indicator of organizational performance,

$\mathrm{X}$ - knowledge workers' participation in the total number of employees.

The coefficient $b$ in the above presented model shows how much each financial indicator of organizational performance will change (rise or decline) if the knowledge workers' participation changes by 1 percent?

Regression parameters which are relevant for explaining the impact of knowledge workers' participation change on each observed financial indicator of organizational performance are presented in Table 3.

Table 3. Regression parameters

\begin{tabular}{lccc}
\hline & Sig. & $\boldsymbol{b}$ & $\mathbf{R}^{2}$ \\
\hline Total assets turnover & 0.359 & -0.049 & 0.025 \\
Current assets turnover & 0.335 & -0.257 & 0.028 \\
Revenues over expenses ratio & $0.005^{*}$ & $0.002^{*}$ & 0.206 \\
Return on assets & 0.586 & -0.002 & 0.009 \\
Return on equity & $0.000^{*}$ & $0.012^{*}$ & 0.366 \\
ROCE & 0.405 & -0.014 & 0.021 \\
Revenue per employee & $0.000^{*}$ & $214,681.60$ & 0.442 \\
& & $*$ & \\
Earnings before taxes per employee & $0.002^{*}$ & $7,041.18^{*}$ & 0.250 \\
Labor costs per employee & $0.000^{*}$ & $2,991.97^{*}$ & $0.687^{* *}$ \\
Revenue per knowledge worker & $0.029^{*}$ & $191,068.70$ & 0.132 \\
& & $*$ & \\
Earnings before taxes per knowledge worker & 0.065 & $12,432.58$ & 0.097 \\
Labor costs per knowledge worker & $0.000^{*}$ & - & 0.324 \\
& & $17,931.40^{*}$ & \\
BEX & $0.005^{*}$ & $0.042^{*}$ & 0.219 \\
Approximation on value added & 0.318 & $1,602,805$. & 0.029 \\
& & 21 & \\
Approximation on value added per knowledge & 0.484 & $-5,501.47$ & 0.015 \\
worker & & & \\
\hline
\end{tabular}

*Regression parameter $\mathrm{b}$ is statistically significant (Sig. $\leq 0.05$ ).

$* *$ Regression model is statistically significant $\left(\mathrm{R}^{2} \geq 0.60\right)$.

Source: Authors’ calculations

It is important to point out that the models presented in Table 3 are models of linear regression. They explore the change of each financial indicator caused by the change of the same independent variable and that is the knowledge workers' participation. Out of 15 financial indicators, in the case of eight of them, it was found that the regression parameter $b$ is statistically significant (Sig 0.05 ). Co ncerning the value of $\mathrm{R}^{2}$, the regression model is 
statistically significant $\left(\mathrm{R}^{2} \geq 0.60\right)$ only in the case of one financial indicator and that is the labor costs per employee, which means that $68.7 \%$ of the dependent variable (labor cost per employee) is explained by the independent variable (knowledge workers' participation). In the case of other financial indicators, $\mathrm{R}^{2}$ is not statistically significant. However, concerning that the topic of this research is the relationship between knowledge workers' participation and financial indicators, the value of $\mathrm{R}^{2}$ in the case of all eight financial indicators, where parameter $b$ of the regression model is statistically significant, could be perceived as satisfactory. This means that, for example, in the case of the revenues over expenses ratio, $20.6 \%$ of this indicator is explained by knowledge workers' participation, which is significant knowing that this is a linear regression model and that the revenues over expenses ratio could be determinated by many other influences than knowledge workers' participation.

Thus, regarding the nature of the analyzed variables (financial indicators are influenced by many different variables besides the knowledge workers' participation), the fact that these models are models of linear regression (the change of each financial indicator is explained by the change of knowledge workers' participation) and that in the case of eight financial indicators, parameter $b$ is statistically significant, the change of eight financial indicators could be explained by the change of knowledge workers' participation. Therefore, based on the value of parameter $b$, it can be determined as follows:

- if the knowledge workers' participation increases by one percentage point, the revenues over expenses will increase by 0.002 units; and vice versa, if the knowledge workers' participation decreases by one percentage point, the revenues over expenses will decrease by 0.002 units;

- if the knowledge workers' participation increases by one percentage point, the return on equity will increase by 0.012 units or by a 1.2 percentage point, and vice versa;

- if the knowledge workers' participation increases by one percentage point, the revenue per employee will increase by 214,681.60 kunas, and vice versa;

- if the knowledge workers' participation increases by one percentage point, the earnings before taxes per employee will increase by 7,041.18 kunas, and vice versa;

- if the knowledge workers' participation increases by one percentage point, the labor cost per employee will increase by 2,991.97 kunas, and vice versa;

- if the knowledge workers' participation increases by one percentage point, the revenue per knowledge worker will increase by 191,068.70 kunas, and vice versa;

- if the knowledge workers' participation increases by one percentage point, the labor cost per knowledge worker will decrease by 17,931.40 kunas, and vice versa;

- if the knowledge workers' participation increases by one percentage point, the BEX index will increase by 0.042 units, and vice versa.

According to this analysis, again, it was found out that the increase of the knowledge workers' participation is not sufficiently covered by additional expenses related to these workers. The presented results show that if the participation of knowledge workers increases, the labor costs per employee slightly grow, while the labor costs per knowledge workers decrease. Therefore, it could be assumed that additional investment in knowledge workers will lead to higher knowledge workers' contribution to organizational performance, which could be realized by enhancing their compensation program or by additionally investing in their education, training and professional development.

\section{CONCLUDING REMARKS}

Knowledge workers have appeared as a result of new demands that are placed in front of modern companies, and they became a significant factor of the company's success. Based on their appearance and existence, the modern society is called the knowledge society in which 
the knowledge workers play a major role. In the present circumstances, in all companies, the major challenge is to attract knowledge workers and put them in positions where they will be able to make the largest contribution to the company. Namely, the success of today's companies depends on management skills and efficiency to attract, retain and motivate knowledge workers (Drucker, 2005).

The empirical results of this paper go in this direction. They suggest the existence of the statistically significant positive correlation between knowledge workers' participation and some financial indicators of organizational performance, implying a significant importance of knowledge workers for companies' performance. However, it should be pointed out that the determined correlations are not strong ones, which is expected because of many different factors which influence and determine the organizational performance, so the generalization of this conclusion should be restrained. The exploration of these correlations, as well as regression parameters defined by the statistical analysis in this paper, imply some further conclusions which regard some particular dimensions of organizational performance. The growing number of knowledge workers increases the total labor costs which include salaries and other costs related to all employees, but at the same time, the increase of knowledge workers' participation is not adequately followed by increased rewards and other expenses which are related to these workers. The discovered low knowledge workers' productivity is not mainly the result of their individual effort and engagement but rather the result of poor organizational conditions and the organization's disability to use the potential of knowledge workers. The productivity of knowledge workers could be improved by increasing financial allocations and companies' expenditure related to these workers, which could be realized through salaries, bonuses, benefits, supplemental insurance, training, specializations, etc. By this practice, their contribution to organizational performance could be enhanced.

\section{RESEARCH LIMITATIONS AND GUIDELINES FOR FUTURE RESEARCH}

Understanding research limitations and their possible impact on the results and conclusions is necessary for adequate understanding of the problem investigated. The first limitation of this study relates to the definition of knowledge workers. For the purpose of the empirical research of this paper, the knowledge workers are defined by the level of their education acquired, namely as workers who have a high education. This kind of definition is used because it provides the most measurable way of determining knowledge workers, although it has certain limitations. It disregards workers who are basically knowledge workers because in their work they use and create new knowledge, innovations, improvements, etc., but they are not highly educated. On the other hand, it cannot be stated that all workers with a high education are essentially knowledge workers.

The following limitation is related to the research sample. The research results take into account 40 companies that have decided to participate in the empirical research. Considering that the research problem of this study is very specific because it examines a very sensitive dimension of a company's operations, i.e. its efficiency and success, it was difficult to recruit a larger number of companies into the research. Therefore, it is necessary to point out some reservations about the representativeness of the research sample, especially when it comes to some general conclusions.

The next limitation is related to the other variables than knowledge workers' participation, which could have a significant impact on organizational performance, but which, because of the limited research scope, could not be included in this research.

The further limitation refers to the analysis of organizational performance, in which only traditional (quantitative or finance) indicators of organizational performance were used. 
However, qualitative measures of organizational performance could not be included because they do not provide the adequate possibility of comparing companies.

The foundation for the future research could be based on these limitations. Thus, in the future empirical researches, a different, more precise definition of knowledge workers should be used. That definition could be based on the number of innovations or improvements which knowledge workers have obtained through their work. Furthermore, other more advanced statistical methods should be applied in order to generate comprehensive conclusions. Finally, it would be interesting to analyze the organizational performance by some qualitative indicators of companies' performance and to compare it with the results obtained through the empirical research of this paper.

\section{REFERENCES}

Altman, E. I., (1968), "Financial Ratios, Discriminate Analysis and the Prediction of Corporate Bankruptcy”, Journal of Finance, 23 (September): 589-609.

Alverson, M., (2000), "Social identity and the problem of loyalty in knowledge-intensive companies”, Journal of Management Studies, 37 (8): 1101-1123.

Argenti, J., (1975), “Company Failure: The Tell Tale Signs at the Top”, The Director, 28: 287-9.

Arthur, M. B., Defillippi, R. J., Lindsay, V. J. (2008), “On Being a Knowledge Worker”, Organizational Dynamics, 37(4): 365-377.

Bakotić, D. (2009), Međuovisnost zadovoljstva na radu radnika znanja i organizacijskih performansi, (Split: Ekonomski fakultet Split).

Baron, J. N., Hanan, M. T., (2002), “Organizational blueprints for success in high-tech startups”. California Management Review, 44 (3): 8-35.

Barry G. B., Milkovich, G. T., (1990), "Organizational Differences in Managerial Compensation and Financial Performance”, The Academy of Management Journal, 33 (4): 663-691.

Beaver, W., (1967), "Financial Ratios as Predictors of Failure, Empirical Research in Accounting: Selected Studies, Supplement”, Journal of Accounting Research, 5: 71-127.

Belak, V., Aljinović Barać, Ž., (2007), "Business excellence (BEX) index - za procjenu poslovne izvrsnosti tvrtki na tržištu kapitala u Republici Hrvatskoj”, Računovodstvo, revizija i financije, 10: 15-25.

Bender, K. A., Donohue, S. M., Heywood, J. S., (2005), Job satisfaction and gender segregation, Oxford Economic Papers, 57: 479-496.

Bendre, K. A., Heywood, J. S., (2006), Job satisfaction of the highly educated: The role of gender, academic tenure, and earnings, Scottish Journal of Political Economy, 53(2): 253279.

Bentley, T., (1990), “The knowledge workers”, Management Accounting-London, 68 (3): 47.

Brigham, E. F., Daves, P.R., (2001), “Intermediate financial management”, (Thompson learning).

Choi, J.S., Kwak, Y.M., Choe, C., (2010), "Corporate social responsibility and corporate financial performance: Evidence from Korea”, Australian Journal of Management, 35 (3): 291-311.

Darchen, S., Tremblay, D. G., (2010), "What attracts and retains knowledge workers/students: The quality of place or career opportunities? The case of Montreal and Ottawa”, Cities, 27: 225-233.

Davenport, T., (2003), “A measurable proposal”, CIO Magazine, June.

Despres, C., Hiltrop, J., (1996), "Compensation for technical professionals in the knowledge age”, Research Technology Management, 39: 48-56. 
Dotson, J.P., Allenby, G.M., (2010), "Investigating the Strategic Influence of Customer and Employee Satisfaction on Firm Financial Performance”, Marketing Science, 29 (5): 895908.

Drucker, P., (1959), Landmarks of Tomorrow: A Report on the New "Post-Modern" World, (republished by Transaction Publishers, 1996).

Drucker, P., (1999), “Knowledge-worker productivity: The biggest challenge”, California Management Review, 41: 79-94.

Drucker, P., (2005), Upravljanje u novom društvu. (Novi Sad: Adižes).

Flamholtz, E., Hua, W., (2002), "Strategic Organizational Development, Growing pains and Corporate Financial Performance: An empirical Test”, European management Journal, 20 (5): 527-536.

Frost, J., Osterlon, M., Weibel, A., (2010), “Governing Knowledge Work: Transactional and Transformational Solutions”, Organizational Dynamics, 39 (2): 126-136.

Griffin, R. W., (2002), Management, (Houghton Mifflin Company).

Gursoy, D., Swanger, N., (2007), "Performance-enhancing internal strategic factors and competencies: Impacts of financial success”, International Journal of Hospitality Management, 26 (1): 213-227.

Harrigan, K. R., Dalmia, G., (1991), "Knowledge workers: The last bastion of competitive advantage”, Planning Review, 19(49): 48.

Harris, M. F., Vining, G. W., (1987), "The IE's future role in improving knowledge worker productivity”, Industrial Engineering, 19: 28-32.

Herzberg, F., Mausner, B., Snyderman, B. B., (1959), The Motivation to Work (2nd ed.), (New York: John Wiley \& Sons).

Horwitz, F. M., Heng, C. T, Quazi, H. A., (2003), "Finders, keepers? Attracting, motivating and retaining knowledge workers”, Human Resource Management Journal, 13 (4): 23-44.

Huselid, M. A., (1995), “The Impact of Human Resource Management Practices on Turnover, Productivity, and Corporate Financial Performance”, The Academy of Management Journal, 38(3): 635-672.

Janz, B. D., Colquitt, J. A., Noe, R. A., (1997), "Knowledge worker team effectiveness: The role of autonomy, interdependence, team development, and contextual support variables", Personnel Psychology, 50: 877-904.

Jing, X., Li, Y., (2008), “The relationship between organizational learning and firms' financial performance in strategic alliances: A contingency approach”, Journal of World Business, 43 (3): 365-379.

Karr-Wisniewski, p., Lu, Y., (2010), "When more is too much: Operationalizing technology overload and exploring its impact on knowledge worker productivity”, Computers in Human Behavior, 26: 1061-1072.

May, T. Y., Korczynski, M., Frenkel, S. J., (2002), "Organizational and Occupational Commitment: Knowledge workers in large corporations”, Journal of Management Studies, 39 (6): 775-801.

Munoz-Bullon, F., Sanchez-Bueno, M. J., (2010), "Downsizing implementation and financial performance”, Management Decision, 48 (7-8): 1181-1197.

Neely, A., (1999), “The performance measurement revolution: Why now and what next?", International Journal of Operations \& Production Management, 19 (2): 205-228.

O'Connor, J. (2007), The impact of affective factors related to work on the turnover intent of speech language pathologists in Texas, (Texas A\&M University).

O'Boyle, E.H, Rutherford, M.W., Pollack, J.M., (2010), "Examining the Relationship between Ethical Focus and Financial Performance in Family Firms: An Exploratory Study”, Family Business Review, 23 (4): 310-326. 
Ohlson, J. A., (1980), "Financial ratios and the probabilistic prediction of bankruptcy", Journal of Accounting Research, 18: 109-131.

Rechner, P. L., Dalton, D. R., (1991), "CEO duality and organizational performance: A longitudinal analysis”, Strategic Management Journal, 12 (2): 155-160.

Redpath, L., Hurst, D., Devine, K., (2009), "Knowledge workers, managers, and contingent employment relationships”, Personnel Review, 38 (1): 74-89.

Reed, M. I., (1996), "Expert power and control in late modernity: An empirical review and theoretical synthesis”, Organization Studies, 17 (4): 573-97.

Roell, M., (2004), "Distributed KM-Improving Knowledge Worker's Productivity and Organizational Knowledge Sharing with Weblog-based Personal Publishing”, taken from http://www.roell.net/publikationen/distributedkm.shtml (21. 01. 2008.)

Santhapparaj, A. S., Alam, S. S., (2005), Job satisfaction among academic staff in private universities in Malaysia, Journal of Social Sciences, 1 (2): 72-76.

Schulte, M., Ostroff, C., Shmulyian, S., Kinicki, A., (2009), “Organizational Climate Configurations: Relationship to Collective Attitudes, Customer Satisfaction and Financial Performance", Journal of Applied Psychology, 94 (3): 618-634.

Sharma, R. D., Jyoti, J., (2010), Job satisfaction of university teachers: An empirical study, Journal of Services Research, 9 (2): 51-80.

Škerlavaj, M., Štemberger, I. M., Škrinjar, R., Dimovski, V., (2007), “Organizational learning culture - the missing link between business process change and organizational performance”, International Journal of Production Economics, 106(2): 346-367.

Snow, C. C., Hrebiniak, L. G., (1980), "Strategy, Distinctive Competence, and Organizational Performance”, Administrative Science Quarterly, 25 (2): 317-336.

Sy, T., Tram, S., O'Hara, L. A., (2006), Relationship of employee and manager emotional intelligence to job satisfaction and performance, Journal of Vocational Behavior, 68(3): 461-473.

Taffler R. J., (1977), “Going, going, gone - four factors which predict”, Accountancy, 88: 5054.

Tucela, C., Tigh. G., (2007), "The management of knowledge workers-Key factors of success”, Management\&Marketing, 1 (1): 171-176.

Vogt, E., (1995), “The nature of work in 2010”, Telecommunications, 29: 21-27.

Wang, Y., Zhu, Z., Cong, Q., (2009), “An Analysis on the Knowledge Workers' Turnover: A Psychological Contract Perspective”, International Journal of Business and Management”, 3 (3): 62-65.

Wu, J., (2009) “On the Management Based on Characteristics of Knowledge Workers”, Modern Applied Science, 2 (2): 51-53.

Xing, Z., (2009), "Impact of University's Optimal Human Resource Management Practices on Organizational Performance”, Systems Engineering - Theory \& Practice, 29 (11): 112-122.

Žager, K., Žager, L., (1999), Analiza financijskih izvještaja, (Zagreb: Masmedia). 


\section{VEZA IZMEĐU UDJELA RADNIKA ZNANJA I ORGANIZACIJSKIH PERFORMANSI}

\section{SAŽETAK}

Cilj ovoga rada je empirijski dokazati vezu između udjela radnika znanja zaposlenih $u$ određenom poduzeću i njegove uspješnosti, te pokazati na koji način promjena udjela radnika znanja utječe na promjenu organizacijskih performansi. Empirijsko istraživanje provedeno je na uzorku od 40 poduzeća, pri čemu su analizirani podaci o udjelu radnika znanja u ukupnom broju radnika te podaci o financijskim performansama poduzeća. Rezultati empirijskog istraživanja ukazuju na vezu između udjela radnika znanja i organizacijskih performansi. Nadalje, rezultati pokazuju da rast udjela radnika znanja nije adekvatno praćen rastom nagrada $i$ drugih troškova vezanih uz ove radnike koji mogu biti značajan faktor niske proizvodnosti ovih radnika koja je ovim istraživanjem također dokazana.

Ključne riječi: radnici znanja, uspješnost, poduzeće, proizvodnost 